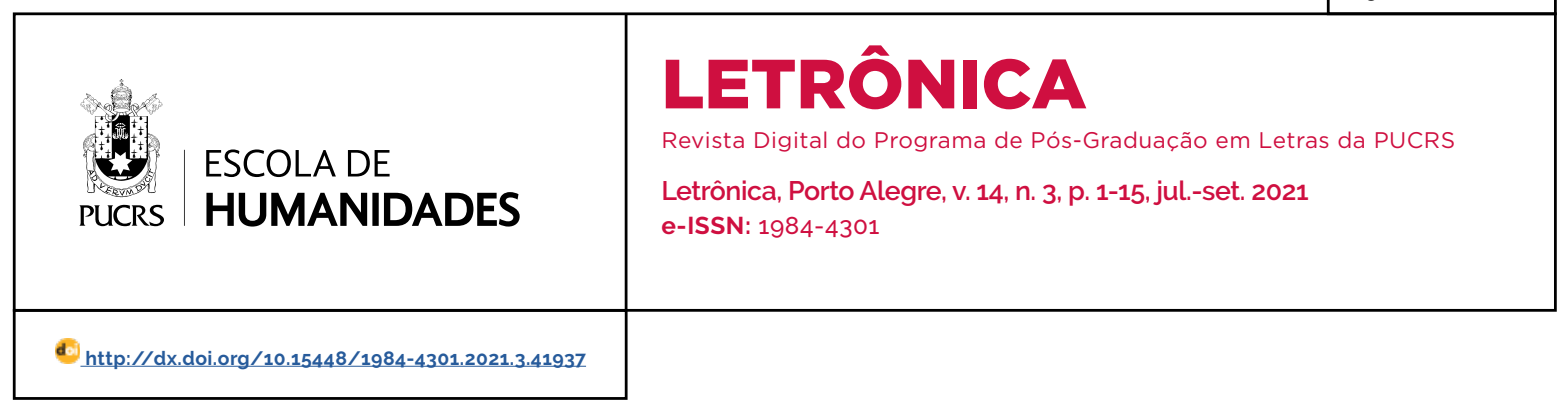

EDITORIAL

\title{
Personagens subalternas nas literaturas de língua portuguesa
}

Subaltern characters in Portuguese language

Maria Tereza Amodeo ${ }^{1}$ orcid.org/0000-0002-5039-4365 mtamodeo@pucrs.br

\section{Sílvia Amorim ${ }^{2}$}

orcid.org/0000-0002-5570-5513 silvia.amorim@u-bordeauxmontaigne.fr

\section{Ívens Matozo Silva ${ }^{1}$} orcid.org/0000-0002-4100-0811 ivens_matozo@hotmail.com

Recebido em: 6 out. 2021. Aprovado em: 7 out. 2021. Publicado em: 9 nov. 2021.

\section{(c) (1)}

Artigo está licenciado sob forma de uma licença Creative Commons Atribuição 4.0 Internacional.
Ao substituir a categoria mais restrita de proletário pela de subalterno, Antônio Gramsci (1999-2002) já deixa evidente a complexidade acerca do termo. O conceito de hegemonia cultural se impõe nesse contexto, já que a subalternidade, além de sua dimensão social, possui componentes culturais e epistemológicos. Esse sujeito subalterno sofre diversas formas de dominação - capitalista, colonial ou machista -, o que o condena ao mutismo, na perspectiva de Gayatri Spivak (1988). Ora, segundo a mesma autora (1987), a representação literária de figuras subalternas constitui efetivamente uma forma possivel de resistência contra-hegemônica.

Diferentemente do que ocorre na contemporaneidade, a frequência e a diversidade das figuras subalternas nem sempre tiveram lugar nas literaturas de lingua portuguesa. É nesse sentido que a presente edição da Letrônica propõe avaliar a diversidade das representações dos sujeitos subalternos, a partir de um corpus alargado de textos, tendo em vista os pressupostos que sustentam essas representações, buscando os mecanismos que põem em causa perspectivas essencializadoras, que revelam fatores de inferiorização.

Sendo assim, verifica-se que o texto literário pode atuar de várias maneiras. Por um lado, enquanto portador de pressupostos e esquemas mentais inquestionados, ele pode ser alvo de uma desconstrução que vem revelar perspetivas convencionais e instituidas. Essa desconstrução, que consideramos aqui num sentido lato, inscreve-se na via aberta pelo filósofo francês Jacques Derrida (1967) ao mostrar que a linguagem não veicula um sentido univoco e estável e que, por conseguinte, a oscilação (différance) que ela contém, é reveladora de dualismos no discurso e na própria realidade do locutor.

A desconstrução põe, assim, em causa as narrativas fundadoras da Modernidade ${ }^{3}$, nomeadamente as que legitimam a supremacia da cultura e do saber eurocêntricos. Por conseguinte, é possivel explorar textos portadores de estereótipos e pressupostos que confortam situações de subalternidade a fim de desvendar os mecanismos e perspectiva que os sustentam. Ao invés, a desconstrução pode decorrer no seio do próprio texto literário, por meio

\footnotetext{
Pontificia Universidade Católica do Rio Grande do Sul, Porto Alegre, RS, Brasil.

Université Bordeaux Montaigne, Pessac Cedex, França.

O estatuto do saber, a sua relação com o poder e a sua legitimidade no contexto pós-moderno são interrogados por Lyotard (1979)
} 
da paródia pós-moderna e do recurso à intertextualidade, que possibilitam o questionamento de textos considerados mais autoritários ou legítimos.

Por outro lado, o texto literário pode ser o lugar em que os silenciados falam e expõem os seus pontos de vista, deixando, desse modo, antever que existem outros lugares de fala na sociedade, além da posição do indivíduo masculino, branco e heterossexual, conforme sugere a filósofa Djamila Ribeiro (2017).

O texto literário pode ser também um lugar de resgate daqueles que a história oficial não registrou, nomeadamente através da metaficção historiográfica e da exploração do passado através de pontos de vistas alternativos, ex-cêntricos (HUTCHEON, 1988). A pesquisadora canadense Linda Hutcheon apresenta, nos seus trabalhos sobre o pós-modernismo, essas narrativas alternativas que reatribuem um lugar ao subalterno. Além disso, o texto literário é também um lugar de recolha de narrativas, testemunhos e memórias que contribuem para consolidar identidades, por vezes negadas.

De fato, a condição subalterna implica questionamentos identitários uma vez que essa posição sonega o sujeito, considerado apenas como Outro e condenado ao apagamento social, cultural, político etc. Já no contexto da descolonização, Frantz Fanon (1952) apontava para a despersonalização como consequência da colonização e criava o conceito de zona de não ser para a qual são rejeitados os colonizados.

Mais recentemente, as teorias decoloniais, desenvolvidas por pensadores da América hispanófona, como Anibal Quijano, Walter Mignolo ou Ramón Grosfoguel, ${ }^{4}$ apontam para a negação das identidades num contexto de persistência de estruturas hegemônicas fundadas nas antigas relações coloniais e em uma retórica da Modernidade que justifica a preponderância do modelo ocidental/eurocêntrico. Boaventura de Sousa Santos, por seu lado, denuncia uma forma de espistemicidio de que é alvo o Sul, ligado à não existência dos saberes e experiências não (re)conhecidos pelos ocidentais. ${ }^{5}$

A ideia de negação da identidade aparece também no ensaio Grada Kilomba (2021) sobre a experiência traumática do racismo. A psicóloga portuguesa considera o racismo comum como um ato de colonização que resulta, para a vitima, no sentimento de não pertencimento à comunidade ou à nação em que vive: "[...] somos observados/as, tratados/as, atacados/as, agredidos/as e por fim aprisionados/as em devaneios brancos" (2021, p. 217). Ora, o texto literário pode ser um lugar de afirmação identitária e de empoderamento enquanto suporte de discursos emancipadores individuais e coletivos.

A literatura também poderá assumir, nesse âmbito, um papel reterritorializador, uma vez que a questão da subalternidade também está fortemente vinculada à noção de espaço. O subalterno ocupa, não raro, um espaço periférico devido à sua condição, uma marginalização tanto simbólica como concreta. No contexto atual de globalização e persistência de clivagens centro/periferia, perpetuam-se e intensificam-se as situações de exclusão ou exílio (fora ou dentro da própria terra), nomeadamente em contexto diaspórico.

A questão do território, enquanto suporte identitário, coloca-se, então, de forma exacerbada, como se pode ver, por exemplo, em um interessante artigo de Yves Clavaron (2019) sobre as geografias subalternas nas literaturas pós-coloniais, que mostra como a literatura pode subverter a fratura norte/sul através de um processo de delinking, relativamente à matriz colonial do poder (sendo o delinking um conceito de Mignolo retomado por Claveron). Através da construção de uma geografia alternativa, as literaturas pós-coloniais literaturas migrantes e literaturas da diáspora em particular - criam novos espaços marcados pelo hibridismo. Nesse contexto, a noção de diáspora torna-se fulcral, assim como enfatiza Claveron:

\footnotetext{
4 Alguns exemplos ilustrativos do pensamento decolonial serão o artigo de Aníbal Quijano "Colonialidad del poder y clasificación social" (2000), o de Ramón Grosfoguel, "Para descolonizar os estudos de economia política e os estudos pós-coloniais: Transmodernidade pensamento de fronteira e colonialidade global" (2012), ou ainda, o livro de Walter Mignolo, Local Histories/Global Designs. Coloniality, Subaltern Knowledges and Border Thinking (2000).

5 A propósito dessa questão, sugere-se o capítulo de Boaventura de Sousa Santos Para além do Pensamento Abissal: das linhas globais a uma ecologia dos saberes (2009).
} 
[...] permitindo romper com o dualismo da estrutura colonial, ultrapassando a oposição Sul/Norte e problematizando as formulações da identidade, a noção de diáspora tornou-se a metáfora privilegiada para caracterizar uma geografia contemporânea, feita de mobilidade, deslocamentos e travessias, que dão lugar a uma reconquista geográfica [...] (2019, p. 451, tradução nossa).

Um dos desafios da ficção contemporânea será a afirmação de identidades vinculadas com esses territórios reconquistados. Fazer uma listagem exaustiva das representações da personagem subalterna nas literaturas de língua portuguesa, além de um interesse limitado, seria uma tarefa impossivel e necessariamente lacunar no espaço reduzido deste dossiê. A nossa proposta antes consiste em realçar algumas tendências e evoluções na abordagem do subalterno, expor temáticas conexas da subalternidade e lembrar alguns autores e obras mais emblemáticas que balizam a história da representação da personagem subalterna na literatura.

Mais propriamente, no contexto da literatura portuguesa, a criada Juliana da obra de 1878 de Eça de Queirós, O primo Basilio, é um arquétipo da personagem subalterna. Embora marginal relativamente ao trio amoroso constituido pelo casal, Luísa e Jorge, e o amante, Basílio, a empregada possui uma complexidade que a torna um autêntico pivô do enredo. Subalterna relativamente aos patrões, mas desempenhando um papel central no romance, é reveladora do poder da literatura de focar os invisiveis. Esse lugar de destaque é sublinhado por Lopes e Saraiva (2005, p. 872), que colocam Juliana num plano semelhante ao de Luisa: "Apesar de a tragédia de Luísa ser a mais desenvolvida e sublinhada, ela é interdependente de outra tragédia: a da criada Juliana, cuja história retrospetiva merece também desenvolvimento pelo narrador". Assim sendo, relata-se o percurso patético de Juliana, "Iclom uma infância de humilhações, mais de vinte anos "a servir", a dormir em cacifos, a comer os restos, precocemente envelhecida, doente e azeda, e por isso odiada e alcunhada" (2005, p. 872). No entanto, se a intenção de Eça é mostrar, com certa ironia, a estratificação social e criticar as normas e costumes da burguesia lisboeta do seu tempo, seu propósito não é propriamente a denúncia da subalternidade. O apelo à subversão das hierarquias sociais aparecerá posteriormente.

Nas primeiras décadas do século 20, a ficção realista verte para "uma alternância entre o pitoresco regional, por um lado, e uma certa atração dos bas-fonds urbanos ou um certo humanitarismo compassivo, por outro" (LOPES; SARAIVA, 2005, p. 1023), o que dá origem a representações de cenários sociais mais míseros, com títulos tão sugestivos como Os famintos (1903), Gente pobre (1912), ${ }^{6}$ Gente rústica (1927), ${ }^{7}$ ou ainda, na mesma veia embora ulteriormente, Servidão (1946) ou Pão Incerto (1964). ${ }^{8}$ Mas o advento do neorrealismo, na década de 1930, em um contexto de repressão política, dará o verdadeiro impulso a uma literatura de intervenção com nítida vertente ideológica, de matriz marxista, representada por autores como António Alves Redol (com o romance Gaibéus (1945), o magnum opus do neorrealismo militante), Ferreira de Castro ou Manuel da Fonseca.

Carlos Reis lembra que

[...] se existem afinidades entre o Neo-Realismo
e o Realismo oitocentista, elas situam-se não
no plano ideológico, mas no plano ético: para
ambos, trata-se, antes de tudo, de ligar a litera-
tura à sociedade, fazendo dela um instrumento
de activa intervenção social (2005, p. 16).

O subalterno é, então, um representante das camadas proletárias alienadas e vítimas de repressão. A sua presença na literatura serve um projeto de consciencialização política num âmbito de lutas interclassistas, ainda que esse projeto esbarre, de certa forma, nas elevadas taxas de analfabetismo do público (em Portugal, em meados do século 20, metade da população é analfabeta). Assim sendo, o subalterno apresenta-se como a pedra angular da literatura de intervenção. Ora, coloca-se a questão da evolução dessa figura em contextos politicos e sociais diferentes, nomeadamente no período pós-ditatorial.

\footnotetext{
Ambos são romances de João Grave (1872-1934). 
O ensaísta francês Gilles Lipovetsky mostra que em um ambiente não repressivo a natureza do compromisso/engajamento muda, uma vez que "o que importa não é tanto tomar posição em defesa disto ou daquilo, mas entender um pouco melhor 'como funcionam as coisas' [...]" (2004, p. 154-155, tradução nossa). Assim sendo, em contextos democráticos, os intelectuais são levados a encarar de maneira diferente a noção de oposição, de luta. Na literatura, o compromisso passa então a ser, segundo a expressão de Alexandre Gefen, um "compromisso da memória ou do testemunho" (fr. "engagement mémoriel ou testimonial"), que deixa de ser ideológico ou político (2005, p. 75-84).

É interessante observar que José Saramago formaliza, no romance Levantado do chão (1980), uma reflexão perspicaz sobre essa transição entre diferentes tipos de compromissos literários no pós-25 de Abril, ${ }^{9}$ com um consecutivo impacto no tratamento da personagem subalterna. Embora o romance, de indole social, tenha como pano de fundo a luta dos trabalhadores rurais do Alentejo contra o poder abusivo dos latifundiários ao longo do século 20, a inserção do romance no paradigma neorrealista seria, obviamente, anacrônica. A nosso ver, Levantado do Chão sugere a impossibilidade do neorrealismo literário, não só porque o contexto social, econômico e político evoluiu, levando ao desaparecimento do mundo rural tal como ele existira até ali, mas, acima de tudo, porque o molde neorrealista, com os seus pressupostos ideológicos, se torna problemático num momento em que se põe em causa as ideologias e narrativas fundadoras da cultura ocidental.

Esse contexto de crise ideológica explica talvez a substituição, por José Saramago, das formas literárias de militantismo por uma "exigência ética e estética" (AGUILERA, 2010, p. 291), que consiste em reabilitar os subalternos, aqueles que não têm visibilidade nem voz, cumprindo um dever de justiça. Esse compromisso traduz-se em nivel formal numa série de elementos estilisticos e estratégias narrativas (enumerações, digressões, polifonia, oralidade, multiperspectivismo, narrador intrusivo e irônico etc.), que dão à escrita saramaguiana o cunho que the conhecemos.

Em Levantado do chão, os camponeses alentejanos vivem cativos dos arcaísmos de um universo latifundiário aparentemente imutável. Porém, ao longo do romance, as personagens integram-se pouco a pouco no espaço e no tempo, o que thes outorga uma possibilidade de atuação social e política. A subversão é uma das vias para conseguir essa integração, nomeadamente através da emancipação da figura feminina, cujo destino parecia determinado desde o início dos tempos: "Das mulheres nem vale a pena falar, tão constante é o seu fado de parideiras e animais de carga" (1980, 125). O final do romance mostra um momento jubilatório em que as personagens percorrem o latifúndio para ocuparem herdades: homens e mulheres, mortos e vivos, humanos e animais erguem-se e caminham lado a lado, sem hierarquia nem cronologia. Obra programática, Levantado do chão anuncia assim uma literatura que passa a ser um lugar de reabilitação e resgate de todos os subalternos que escapam, assim, ao esquecimento, ao anonimato e ao silenciamento.

Ao acompanhar a transição pós-moderna, nomeadamente com a publicação de metaficções historiográficas, José Saramago abre novos caminhos na ficção portuguesa. Romances como Memorial do convento (1982) ou História do cerco de Lisboa (1989), instauram um diálogo com a história oficial produzida pelas elites vencedoras e vão assim questionando a sua legitimidade e autoridade enquanto representação do passado. Revelando as lacunas e os principios hierarquizantes que sustentam essas narrativas aparentemente inquestionáveis, José Saramago propõe versões alternativas, com o toque irônico da paródia pós-moderna (HUTCHEON, 1978).10

Aplicando o principio pós-moderno de não seleção e de recusa das diferenças hierarquizantes (FOKKEMA, 1988), Saramago vai recuperando

\footnotetext{
9 Assim como já fizemos em AMORIM, S. Levantado do Chão: anacronismos e novos compromissos literários. Revista de Estudos Saramaguianos, [S. I.], v. 1, n. 12, p. 49-66, ago. 2020.

10 Ver em particular a p. 476
} 
aspetos residuais do passado, interessando-se pelas margens e dando lugar às vozes e pontos de vista ex-cêntricos (HUTCTCEON, 2000). José Saramago opta assim pelos caminhos menos trilhados, explorando os interstícios e pormenores da História, mostrando que estes são tão relevantes para a compreensão do passado como os acontecimentos que ficaram formalmente registrados. $\mathrm{O}$ autor mostra assim que aquilo que se conta sobre o passado é apenas uma opção entre uma infinidade de escolhas possíveis. Nessa perspetiva, a personagem subalterna é aquela que o autor vai seguir para encarar os acontecimentos de forma alternativa, permitindo o questionamento das certezas e a exploração de novos recantos do passado.

A exploração do passado através da ficção no intuito de salientar e pôr em causa pressupostos ideológicos e construções hegemônicas também se encontra com frequência na literatura pós-colonial. O romance $A$ costa dos murmúrios, de Lídia Jorge (1988), é representativo desse empreendimento de ressignificação do passado pelo recurso a uma perspetiva alternativa. Partindo de uma pequena narrativa, "Os gafanhotos", assumida por um narrador masculino, a personagem de Eva relata novamente os acontecimentos vividos em Moçambique, no tempo do seu casamento com um militar português envolvido na guerra colonial. Numa sociedade dominada pelo homem branco em que prevalecem critérios de virilidade, Eva depara-se com a violência da dominação masculina que congrega vários poderes, em particular o patriarcado e o domínio étnico-racial. ${ }^{11}$ Mais recentemente, o romance de Isabela Figueiredo, Caderno de memórias coloniais (2009), também explora o contexto da colonização portuguesa em Moçambique, mas, dessa vez, através da perspetiva de uma menina que testemunha o racismo do próprio pai na época colonial. A exposição dessa memória vai assim abalando o mito de uma colonização portuguesa mais pacífica e cordial do que as demais.

Dessa forma, podemos destacar temáticas conexas da subalternidade que atravessam a história literária portuguesa das últimas décadas dando origem a evoluções originais do ponto de vista do tratamento da figura do subalterno. Já referimos, mais acima, a questão da emancipação feminina ou a da adoção do ponto de vista marginal da mulher em contextos de patriarquismo avivado (ditadura, colonização etc.). Contudo, parece-nos mais pertinente explorar a figura do trabalhador, amiúde associada com a do migrante precário, devido à renovação constante dessa personagem em função da evolução do contexto socioeconómico.

Lembremos que existe em Portugal uma tradição da literatura de migração (DECLERCQ, 2011, p. 201), ${ }^{12}$ desde obras como Emigrantes (1928), de Ferreira de Castro, sobre o fracasso da ida para o Brasil, passando pelo drama da emigração vivido pelas mulheres que veem partir os maridos para outros continentes (como em Viúvas de vivos, de Joaquim Lagoeiro, de 1946, na veia neorrealista) ou os múltiplos testemunhos e relatos sobre a experiência da emigração dos anos 1960-70 (de que são exemplos as narrativas de Nita Clímaco ou Mário Ventura). Nesta última categoria destaca-se o romance de Olga Gonçalves, Este verão o emigrante là-bas (1978), interessante do ponto de vista da técnica narrativa, entre o inquérito sociológico, o testemunho e o relato. Na França, surpreendidos durante as suas atividades e conversas quotidianas mais triviais, as vozes dos trabalhadores portugueses são capturadas pela narradora (que por vezes se apaga, deixando as personagens expressarem-se). A representação da oralidade é trabalhada de modo a reproduzir as interferências entre as linguas portuguesa e francesa, criando a ilusão de uma linguagem espontânea. Assim, o leitor partilha as vivências das personagens no dia a dia, atento a discursos

11 Essa combinação dos critérios de raça e gênero como instrumentos de dominação é aliás analisada por Anibal Quijano Para o sociólogo peruano, a matriz colonial (fundamentada na exploração da força de trabalho, no patriarcado, na dominação étnico-racial e no controlo das formas de subjetividade) ainda rege, hoje em dia, as relações sociais. Quijano destaca em particular a mistura dos critérios de gênero e de raça no âmbito da "colonialidade" (2007).

12 A pesquisadora belga acaba por adotar o termo littérature de migration (port. "literatura de migração"), visto que "junta num mesmo conceito as literaturas feitas pelo migrante, para o migrante e sobre a figura do migrante e seu processo migratório" (DECLERCQ, 2011, p. 310, tradução nossa). 
e aspectos da emigração que the escapariam se não ficassem registados no romance.

É interessante notar que o gênero da literatura de migração se tem renovado de forma frutifera, nomeadamente com a publicação de Livro (2010), de José Luis Peixoto. Os emigrantes são retratados, no início do romance, de maneira aparentemente tradicional: Ilídio, Adelaide, Cosme, dentre outros, seguem um itinerário semelhante ao de milhares de portugueses que deixam as aldeias, nos anos 1960-1970, para ganharem a vida na França (com a passagem das fronteiras, por vezes a salto, a precariedade da vida nos bairros periféricos de Paris, os empregos subalternos, as saudades dos entes queridos...). Porém, a segunda parte do romance subverte totalmente a primeira: Livro é simultaneamente a personagem e o livro que só podem existir porque existiu a emigração, com todas as suas implicações. O subalterno é, nesse caso, reabilitado pela posteridade (note-se que os pais de José Luís Peixoto viveram a experiência da emigração para França), tendo a história valorizada pela literatura e pela projeção, no futuro, de uma experiência afinal fecunda, geradora de novos encontros e expetativas.

As novas migrações, impostas pela globalização, são evocadas na obra de Ricardo Adolfo, nomeadamente no romance Depois de morrer aconteceram-me muitas coisas (2009), em que o emigrante precário, invisivel, incapaz de comunicar e confrontado com um sentimento de ilegitimidade, vê a sua identidade abalada. Em Tóquio vive longe da terra (2015), o mesmo autor vale-se da própria experiência no Japão para evocar o sentimento de ser sempre um "alien", apesar de todas as tentativas de integração numa sociedade impenetrável.

Nesse panorama, podemos também referir O Retorno (2011), de Dulce Maria Cardoso, sobre o regresso precipitado dos portugueses à metrópole na sequência das independências dos territórios ultramarinos. De cunho autobiográfico, o romance evoca a mudança na escala social das personagens regressadas das antigas colônias africanas: ao chegarem a Portugal os retornados são alvo de preconceitos e discriminações, vendo assim a sua identidade alterada.
Além disso, a temática da migração vincula-se também com a questão das diásporas africanas no território português, com a consequentes negociações identitárias, hibridismos e reativações do passado colonial. Podemos mencionar a esse propósito alguns exemplos, como O Vento Assobiando nas Gruas (2002), de Lidia Jorge, ou mais recentemente Luanda, Lisboa, Paraiso (2018), de Djaimilia Pereira de Almeida.

Os trabalhadores nacionais ou oriundos dos países do leste europeu são os protagonistas subalternos do romance de Válter Hugo Mãe, $O$ apocalipse dos trabalhadores (2008), uma reflexão sobre a condição dos trabalhadores no contexto da globalização e sobre as motivações, sonhos e esperanças de personagens afinal menos materialistas do que se poderia pensar. Por fim, podemos referir um romance em que o tratamento da personagem subalterna nos parece original, fazendo eco a problemáticas contemporâneas: O destino turistico (2008), de Rui Zink, leva-nos para um cenário distópico em que Portugal se torna um lugar de turismo de guerra. Os portugueses passam então a receber estrangeiros mais afortunados, estando assim reduzidos a uma precariedade semelhante à dos habitantes das zonas mais violentas e desfavorecidas do planeta. A ambiguidade da personagem subalterna Amadou/Amado, taxista português, sugere a porosidade e relatividade da fronteira entre o EU pertencente à norma (neste caso, à Europa) e o Outro, estranho, pobre, subalterno. Uma fronteira tênue que qualquer um pode vir a atravessar.

Na sequência desta breve apresentação, verificamos a permanência, ao longo do tempo, da figura da personagem subalterna no panorama literário português, embora com implicações diferentes consoante os contextos. A emergência do Pós-modernismo ou do pensamento pós-colonial, por exemplo, contribuiram significativamente para dar novos impulsos às representações do subalterno na literatura.

No que diz respeito à literatura brasileira, o quadro de representação dos subalternos ganha contornos muito especificos, tendo em vista, principalmente, três fatores que deixaram - in- 
felizmente, até nossos dias - marcas indeléveis, não só nos modos de agir dos brasileiros, mas também nas formas de nos retratar por meio da cultura. O primeiro deles relaciona-se à condição de colônia, imposta oficialmente ao país por cerca de três séculos; o segundo, à escravidão infligida aos negros trazidos da África; o terceiro, aos processos de exploração e dizimação dos povos indígenas, os primeiros habitantes da terra brasilis.

Um recorrido, mesmo que breve, pela história do Brasil (o que não é o objetivo aqui), poderia explicitar os modos como nos construímos ao longo dos séculos em relação aos fatores sinalizados, determinantes de comportamentos, políticas públicas e representações que constroem e perpetuam estereótipos. Esses parecem se amalgamar aos olhares e perspectivas de variadas ordens e categorias, quer seja contra os indígenas, ou negros, mulheres ou pobres deste país, incluindo-se os imigrantes que, em várias ondas e por diferentes motivos, transformaram o Brasil em um local para viver.

Estreitando o nosso foco para a literatura, as palavras de Antonio Candido no início da sua antológica Formação da literatura brasileira, são provocativas: "a nossa literatura é galho secundário da portuguesa, por sua vez arbusto de segunda ordem no jardim das Musas... Os que se nutrem apenas delas são reconheciveis à primeira vista, mesmo quando eruditos e inteligentes, pelo gosto provinciano e falta de senso de proporções" (1981, p. 9). A coletânea, redigida entre os anos de 1945 e 1951, sugere, inicialmente, uma visão da literatura brasileira que, se não revista durante a longeva produção do crítico literário, foi marcada por outras nuances, menos dogmáticas e, diriamos, deterministas. Ligia Chiapinni, em ensaio sobre a referida obra do autor, admite que Candido reconhece as manifestações literárias esparsas ocorridas até o século XVI, que se intensificaram, de certa forma, ao longo do XVII, atribuindo, entretanto, principalmente ao Romantismo, os momentos decisivos da formação da literatura brasileira (1990).

O olhar de Candido para a nossa literatura dos inícios já revela a vinculação com os padrões portugueses, o que efetivamente indica um nível de subalternização já do nosso próprio fazer literário, que muito resistiu em encontrar suas próprias formas. Nessas hesitações oitocentistas, é possivel já evidenciar formas de desvalorização das figuras subalternas da sociedade retratadas nos romances românticos, em especial os urbanos, em que a elite da sociedade carioca, por exemplo, mostra-se querendo ser corte. Agia, pois, como se, para definir, reforçar o espaço social privilegiado de que desfrutava, precisasse aniquilar, apagar os subalternos social, simbólica e economicamente por meio de referências pejorativas, formas de nomeação isentas de qualquer pessoalidade ou, simplesmente pelo total apagamento.

O narrador de A moreninha, obra de Joaquim Manoel de Macedo, de 1844, por exemplo, para enaltecer a jovem protagonista, Carolina, não hesita em salientar a rudeza física da escrava, que assim se tornara por servir seus senhores: "mergulhando suas mãos, tão finas, tão lindas, nessa mesma água que fizera lançar um grito de dor à escrava, quando aí tocara de leve com as suas, tão grosseiras e calejadas!" (1982, p. 62). A escrava Tomásia, referida pelo narrador também como "objeto indiferente" em oposição à nobreza de Carolina, denominada por essa de "estonteada" (1982, p. 61), mais do que apagada, como ocorre com as várias escravas presentes nas narrativas românticas brasileiras, é absolutamente estereotipada. A imagem negativa associada a escravas e escravos e, por extensão aos pobres em geral, parece se constituir como elemento estruturante da visão romântica da sociedade.

Já Memórias de um sargento de milícias, de Manuel Antonio de Almeida, por ser o filho desgarrado do Romantismo, provocou uma série de indagações por parte dos críticos, conforme aponta Antonio Candido no seu conhecido "A dialética da malandragem" (1970). O romance, antes considerado como picaresco, passa a ser problematizado por Candido, que vê na obra uma unicidade ímpar, que não se ajusta a rótulos, uma vez que traz à baila a realidade das camadas mais populares da sociedade carioca, diferentemente das formas idealizadas e pretensamente sofisticadas retratadas pelos contemporâneos de 
Almeida, tendo em vista ser o protagonista de origem humilde, cujo nascimento foi atribuido a uma relação fortuita entre seus progenitores: "era filho de uma pisadela e um beliscão" (1998, p. 15).

A perspectiva dos subalternos se complexifica, por exemplo, no romance machadiano, conforme aponta Roberto Scharwrz em seu ensaio "A velha pobre e o retratista" (1983). O crítico aborda a frustração do trabalho sem mérito na personagem Dona Plácida de Memórias póstumas de Brás Cubas, de Machado de Assis. Na sua faina diária, em que desempenha uma série de atividades para sobreviver, Dona Plácida deixa entrever que "a pobreza está descrita no seu ciclo regrado, por assim dizer funcional, e que não falta método ao seu absurdo" (1983, p. 49). O modelo escravagista, que impõe a atividade sem descanso, é substituido, de certa forma, pela mão de obra barata, que não tem qualquer reconhecimento social.

Nessa medida, cabe recuperar o prefácio do livro de Beatriz Resende, Lima Barreto e o Rio de Janeiro em fragmentos, em que Antonio Arnoni Prado salienta que a ensaista traz aos leitores "um narrador moldado nas ruas pela visão dilacerada dos que não têm voz" (2016, p. 8), referindo-se, naturalmente, a Lima Barreto. Efetivamente, já na virada para o século XX, Barreto traz à baila personagens perdidos na cidade, que se encontram no limiar da sanidade, assim como ele. Entretanto, sua obra só teria o devido reconhecimento após a década de 50 do século XX, talvez pela agudeza com que descortina as idiossincrasias de vozes caladas ao longo da história do Brasil.

E o século XX desponta com uma profusão de obras e personagens que registram, redimensionam, desconstroem a realidade brasileira dos excluidos, subalternizados - retratados a cada tempo, de acordo com as formas e contextos que se abrem. O sincretismo de Macunaíma, de Mário de Andrade, que radicaliza na desconstrução das imagens associadas ao negro, ao branco e ao indigena. Mais adiante, Vidas secas de Graciliano, com seu Fabiano, o retirante nordestino que nos comove até hoje, com sua luta para a sobrevivência - ainda tão necessária para boa parte dos brasileiros. E o romance de 1930 é pródigo na representação desses brasileiros alijados do poder econômico e do prestígio social. Assim como, mais adiante, e de forma magistral, o sertanejo é desconstruído da imagem de bandido e retratado na sua humanidade e densidade dramática no grande Grande sertão: veredas, de Guimarães Rosa. E tantos outros.

E a pergunta que, hoje - felizmente, mais do que nunca -, nos fazemos relativamente à representação dos subalternizados diz respeito à figura da mulher, melhor dizendo, das mulheres, ao longo da literatura brasileira. O século XIX é pródigo na representação de mulheres das classes mais favorecidas, subalternizadas pelo patriarcado, pelo contexto que thes exigia posturas reclusas, associadas ao casamento como fim e destino. São muitos os exemplos. José de Alencar é produtivo nessa figuração. Até a Isaura de Bernardo Guimarães, em Escrava Isaura (obra de 1875), que discute a escravidão e o racismo, acompanham o seu tempo, na caracterização da mulher, ainda investindo no matrimônio como possibilidade de garantir o respeito da sociedade.

Mesmo sem nunca ter se vinculado aos movimentos feministas de seu tempo, em 1960, Clarice Lispector resgata, em Laços de família as mulheres que, aparentemente sem dificuldades financeiras, estão exaustas dos papéis que lhes foram destinados, de gestoras do lar, da maternidade, a quem se atribuiam (ou atribuem?) o sucesso do casamento, assumindo, paradoxalmente, papéis de fragilidade e conformismo.

E, na contemporaneidade, a profusão de grandes escritoras parece permitir vir à tona as tantas perspectivas possiveis de ver o mundo, não mais somente pelas lentes dos homens. Assim que elas - Ana Paula Maia, Maria Valéria Resende, Natália Polesso, Verônica Stigger, Jarid Arraes, Conceição Evaristo, Elvira Vigna, Paloma Vidal, Carol Bensimon, Tatiana Salem Levy e muitas mais - fazem surgir tantas outras por meio de suas personagens que reconfiguram a própria literatura brasileira naquilo que se firmou ao longo do século XIX, estendendo-se por boa parte do XX -, ou seja, a perspectiva que anula, exclui, reduz, subalterniza a complexidade do universo feminino. 
Ao mesmo tempo, no Brasil das periferias nas últimas décadas do século $X X$ e no XXI, surgem nomes de autoras e autores que reconfiguram a relação entre realismo e literatura. João César do Castro Rocha, com seu "A Guerra dos relatos no Brasil contemporâneo. Ou: a dialética da marginalidade" (2006), revisa o ensaio fundador de Candido (referido antes), já que assegura o espaço da literatura marginal, que se fortalece cada vez mais no país, por meio de nomes como Paulo Lins e Ferréz, dentre tantos que poderíamos relacionar, tais como: Sacolinha, Sérgio Vaz, Geovani Martins, José Falero etc.

Assim que, em função das épocas e dos contextos sociais, políticos e econômicos, os autores vão experienciando formas variadas de compromisso, apresentando-se quer como observadores satíricos de hierarquias sociais, quer como porta-vozes das classes mais humildes, quer como humanistas resgatadores de anónimos injustiçados, ou ainda, como denunciadores de novas discriminações em contextos globalizados. Ora, essas evoluções na própria noção de compromisso vão dando novos contornos à subalternidade no texto literário.

Uma tendência significativa na literatura atual, no contexto conturbado e instável que Zygmunt Bauman (2001) chama de "Modernidade líquida", consiste em lembrar a relatividade e instabilidade do próprio estatuto subalterno. De facto, os lugares mudam cada vez mais velozmente: as hierarquias invertem-se em função do espaço, do tempo ou da perspetiva. O subalterno (figura feminina inferiorizada, membro de uma diáspora, migrante etc.) pode então vir a ser o autor evocando a própria vivência (e escapando, de certa forma, à subalternidade), lembrando assim que a literatura é um espaço aberto de expressão, visibilidade e resistência.

A revisão acerca das personagens subalternas da literatura portuguesa e da brasileira aqui desenvolvida não se pretendeu exaustiva, tampouco linear. Embora focalizadas separadamente, ambas apresentam muitos pontos de convergência, em especial em relação ao tratamento dos temas vinculados às personagens subalternas. Dessa forma, buscando proximidades temáticas, apresentamos, a seguir, em linhas gerais, os artigos daqueles autores que acolheram a proposição do dossiê.

\section{Representações da subalternidade em épocas passadas}

Identificar hierarquias de sexo, raça ou classe social poderá constituir o primeiro passo para a superação de uma ordem que, à primeira vista, parecerá natural ou inquestionável. Autores como Machado de Assis ou Adolfo Caminha retratam com perspicácia, em um projeto de escrita Realista, o contexto brasileiro das últimas décadas do século 19, revelando uma sociedade patriarcal, ainda vinculada à escravatura, sujeita a preconceitos e discriminações inerentes à época. É possivel reler esses textos, hoje em dia, exumando as relações de poder que neles se manifestam, no intuito de apreender os princípios e mecanismos que sustentam essas relações.

Essa é a proposta de Antonia Claudia de Andrade Cordeiro, em "A figura da mulher subalterna em Machado de Assis: uma análise do conto Capítulo dos Chapéus", ao analisar a construção da personagem feminina de Mariana num conto machadiano de 1883. Enclausurada no lar e no matrimónio, Mariana apresenta-se como uma figura subalterna, discreta, dócil e finalmente pouco consciente da sua posição. Ao retratar Mariana, combinando a perspetiva do narrador com a das demais personagens, Machado de Assis revela a condição da mulher na sua época, propondo assim uma reflexão sobre as relações de gênero e sugerindo - nomeadamente através de Sofia, uma personagem feminina mais emancipada algumas evoluções nessa relação de dominação.

Outra forma de subalternidade, baseada desta vez em critérios de raça e orientação sexual, é analisada no artigo "Entre Bom-Crioulo e Amaro: pode um sujeito negro homossexual falar?", de Carolina Marinho Marcilio, Elisamar Pereira Martins, Yago Jose Eloi do Nascimento e Luciana de Mesquita Silva. Ao encenar a personagem de Amaro, sujeito negro e homossexual, Adolfo Caminha não deixa, em 1895, de indignar o público, induzindo uma recepção negativa do romance no momento da sua publicação. Debate-se no artigo a questão da 
perspectiva de um narrador que fala por Amaro deixando finalmente pouco lugar à subjetividade da personagem e condenando-a assim, de certa forma, ao silêncio. Além disso, sendo o protagonista tão afastado das normas da época, será dificil determinar se o romance contribuiu para abrir novas perspectivas na sociedade oitocentista, ao realçar a sua diversidade, ou se pelo contrário a obra confortou formas de exclusão.

Mais recentemente, no contexto da literatura portuguesa do século 20, José Saramago aborda a questão da subalternidade feminina regressando aos primeiros tempos do cristianismo. Assim, em O Evangelho segundo Jesus Cristo, um romance publicado em 1991, o prêmio Nobel procura no intertexto religioso os fundamentos do lugar historicamente subalterno das mulheres. Em Um sidur para Saramago: de orações e personagens em "O evangelho segundo Jesus Cristo", Sara Grünhagen debruça-se em particular sobre os textos religiosos judaicos referidos no romance, mostrando a abordagem simultaneamente crítica, histórica e ficcional operada por José Saramago. A autora sublinha a importância da recuperação desses textos para a construção das personagens e para a imersão no contexto histórico-cultural da época de Jesus Cristo. Mas além disso, ao serem introduzidos na narrativa, esses textos são alvo de uma subversão que põe em causa os alicerces dos juizos e pressupostos neles contidos.

\section{Identidade e subalternidade: exploração, exclusão e contextos diaspóricos}

O subalterno é também a personagem que vive na periferia, nas margens de uma sociedade que o exclui por não preencher os critérios que o integrariam na norma em vigor. Esse exilio, por vezes na própria terra, abala a identidade: 0 sujeito, percebido como diferente, constrói-se como Outro, existindo apenas como alteridade. No ensaio Mémoires de la plantation. Épisodes de racisme ordinaire (publicado em inglês em 2008 e em uma versão francesa em 2021), Grada Kilomba analisa esse paradoxo, vivido pelo sujeito negro, de ser considerado estranho no próprio país, em uma perpétua situação de "incompati- bilidade com a nação" (KILOMBA, 2008, p. 106). O território deixa de ser, nesse caso, um suporte da identidade, e o grupo a quem se nega a identidade acaba por ocupar um não-lugar (escondido, periférico). Grada Kilomba insiste no facto de a verdadeira descolonização acontecer quando o sujeito "deixa de existir enquanto Outro, mais sim como EU" (KILOMBA, 2008, p. 229). Ora, o texto literário pode ser o lugar da recuperação dessa identidade e de uma forma de reterritorialização.

Situando-se na perspetiva da decolonialidade e da conceção da colonialidade enquanto modo de supressão do Outro (Mignolo) Ilse M. R. Vivian interroga-se, em "O desterro de ser: exílio, resistência e decolonialidades na narrativa brasileira contemporânea", sobre a construção do ser quando confrontado com estruturas hegemônicas em contextos de exilio. Partindo de Becos da memória (2006), de Conceição Evaristo, e Com armas sonolentas (2018), de Carola Saavedra, Ilse Vivian interroga a configuração das identidades daqueles que sofrem a violência do desterro. Nesses romances cruzam-se várias vozes, experiências e temporalidades em narrativas marcadas pela fragmentação: os múltiplos relatos feitos a Maria-Nova em um contexto de expulsão dos habitantes da favela (em Becos da memória), e vozes de quatro mulheres espalhadas pelo mundo em situação diaspórica no romance de Carola Saavedra. Ao refletir sobre a construção da memória através do relato testemunhal que coalesce experiências múltiplas, a autora mostra como as identidades se reinventam individual e coletivamente fazendo contraponto às estruturas hegemônicas e globalizantes.

O romance de Conceição Evaristo é também abordado por Jaisa Girardi Morais e Raissa Lauana Antunes da Silva em Becos da Memória: identidade e memória na construção da narrativa e de personagens subalternas". As autoras evidenciam o necessário resgate da memória de uma coletividade afrodiaspórica para conseguir a emergência de identidades individuais e coletivas. Identidade e memória, estreitamente ligadas com o espaço da favela, estão ameaçadas de dispersão por uma firma construtora que representa as forças impedidoras do processo de reconstrução identitária. Por fim, 
o artigo salienta também a necessária legitimação, pelo/no romance, das narrativas de personagens subalternas habitualmente silenciadas, narrativas que vêm questionar a narrativa dominante.

No contexto da globalização, o subalterno é também o trabalhador rejeitado para as margens da sociedade capitalista. Natália Lima Ribeiro explora, em "Cinzas, sujeiras e porcos: os trabalhadores subalternos de Ana Paula Maia", os romances Entre Rinha de Cachorros e porcos abatidos (2009a), O trabalho sujo dos outros (2009b) e Carvão Animal (2011), revelando a animalização progressiva de homens cuja identidade é esmagada pela postura de submissão induzida por trabalhos avassaladores. No artigo, analisa-se o processo de embrutecimento e deformação humana (mental, social e orgânica) sustentado pela subalternidade, não deixando de ligar a temática identitária com uma dimensão territorial: a face escondida dos centros urbanos faz eco à situação marginal do indivíduo subalterno, então comparado com um resíduo da sociedade.

\section{Individuação, recuperação e consideração da perspectiva do sujeito subalterno}

A narrativa e o resgate da memória, assim como a ligação a um território redefinido na sua hibridez e complexidade contribuem para definir identidades em perdição em contextos de subalternidade. Porém, é possivel evidenciar outras estratégias nas obras literárias, que passam por exemplo pela individuação e pela representação de grupos subalternos que apresentam uma heterogenidade. Além disso, o espaço literário, polifónico, é também um lugar de confronto de pontos de vistas e reinterpretações.

Luciana Persice Nogueira-Pretti analisa, em "Personagens subalternas em Milton Hatoum: medindo silêncios em três romances", a representação de três personagens subalternas: Anastácia Socorro (Relato de um certo Oriente, 1989), Domingas (Dois irmãos, 2000) e Naiá (Cinzas do Norte, 2005). Embora apresentando pontos comuns, as três empregadas revelam também a heterogeneidade do grupo em que se inserem. $\mathrm{O}$ artigo mostra como Milton Hatoum escapa à reprodução de uma personagem-tipo através de processos de individuação dos subalternos e valoriza a presença dessas personagens conscientes da sua condição de sujeição. Além disso, é possivel delinear na obra uma reflexão mais geral sobre a subalternidade, mostrada como sendo plural e gradativa.Num intento próximo, e trabalhando também com o corpus de Milton Hatoum, Juciane Cavalheiro e Augusto Rodrigues da Silva Júnior analisam, em "Relatos da subjetividade: personagens subalternas na obra de Milton Hatoum", as personagens subalternas Anastácia Socorro, de Relato de um certo Oriente, e Domingas, de Dois irmãos, que vivem em contexto de submissão, subalternizadas pela sociedade brasileira e levadas a abdicar as suas identidades. Trata-se, no artigo, de mostrar como essas vozes se autonomizam e passam a habitar, de forma consciente, a história e a cultura. Dessa forma evidenciam-se os processos que levam ao reconhecimento da subjetividade e da identidade.

Em "Mulheres, História e Literatura: reflexões sobre a representação feminina em diferentes momentos da obra de Pepetela", Letícia Alves Franzini e Daniel Marinho Laks analisam duas obras do autor angolano Pepetela, A geração da utopia (1992) e Se o passado não tivesse asas (2016). Situando-se na confluência do pós-moderno e do pós-colonial, na interface entre o literário/ ficcional e a história, o artigo propõe uma análise da representação do subalterno (neste caso a figura feminina) através da construção do seu ponto de vista singular sobre a sociedade e a história angolana. Ao adotar uma visão do país a partir das margens, Pepetela propõe pontos de vista alternativos e críticos sobre os acontecimentos a fim de construir uma representação mais plural da nação, afastada do ideal de representação homogeneizante. Ao reavaliar o passado a partir das margens, o autor revela também os problemas da nação angolana, elaborando uma crítica social.

\section{Silêncios e gritos dos subalternos: violência e mecanismos de opressão}

Aos subalternos social, economica ou simbolicamente constituidos por vezes resta somente 
o silêncio, que potencializa frustrações e agudiza os traumas. Em outras situações é o grito que funciona para enfrentar os mecanismos de opressão instituidos. Os artigos em questão aprofundam essas reflexões em relação a personagens subalternas da literatura brasileira.

Em "Lavouras e silêncios: uma leitura das personagens Ana e André nas obras de Raduan Nassar e Luiz Fernando Carvalho", Jacqueline de Moraes e Silvae Genilda Azerêdo associam a concepção psicanalítica de silêncio ao estudo sobre materializações do silêncio em duas linguagens semióticas distintas - a literatura e o cinema -, no que se refere à inserção subalterna das personagens na familia, focalizando a relação de incesto, que desencadeia a culpa. Silenciando palavras e/ou memórias, as personagens, protagonistas nas narrativas, são discriminadas, subalternizadas por suas escolhas.

No que se refere à representação literária de mulheres, como individuos subalternizados pela submissão imposta pela sociedade machista, a partir das concepções dos estudos feministas, temos como contribuição para essa discussão os seguintes artigos:

a) "Entre o silenciamento e a busca por expressão: a representação da voz feminina subalterna em Livia GarciaRoza", de Wilma dos Santos Coqueiro, que examina o romance Meu marido na perspectiva dos conflitos vividos por mulheres silenciadas pelas relações amorosas opressivas. Nesse sentido, faz uma recuperação dos estudos feministas, direcionando o foco de sua reflexão para a personagem Bela, compreendida como a representação da voz subalterna feminina no romance.

b) "Descolonizando a violência contra as mulheres subalternas em Elvira Vigna", em que Gardênia Dias Santos e Carlos Magno Gomes discutem a obra Como se estivéssemos em palimpsesto de putas, no que diz respeito às formas de legitimação e naturalização da violência contra a mulher, que a autora desmascara, desconstruindo os discursos e atitudes masculinas, calcados em valores como virilidade e honra.

\section{Subalternidade e construção da identidade nacional}

A identidade nacional tem sido mote para tantas manifestações culturais, englobando manifestos, tratados, campanhas publicitárias, programas de governo, obras literárias, e outros. Reunir a diversidade, a pluralidade do povo brasileiro em ideias, personas, propostas univocas têm sido tarefa inócua, infrutifera. Os artigos a seguir descritos problematizam questões de subalternidade nessa discussão acerca do que nos identifica como nação.

Arlindo Ferretti Junior, Euler Renato Westphal e Roberta Barros Meira, em "O Jeca no laboratório: natureza, ciência e identidade nacional em Monteiro Lobato", problematizam a antológica figura da personagem como protagonista da trajetória do autor na proposição de um projeto de Brasil. Jeca Tatu, ao longo da produção/ação política de Lobato, transita entre o pessimismo e a esperança, alcançando ao final a redenção, porque já que, distante do atraso que personificava, assumindo a subalternidade, passou a ser tratado como modelo de brasilidade.

Em "Brasil ou Brasis?: diversidade, divisões e hibridismo cultural em o Cortiço de Aluísio Azevedo", Francinaldo Pereira da Silva e Lucélia de Sousa Almeida denominam de macro e de microcósmico as duas visões culturais distintas que podem ser identificadas no romance. Na primeira, a sociedade é culturalmente dividida em alta e baixa cultura, o que se evidencia na trajetória de João Romão; na segunda, as personagens Firmo, Pórfiro e Rita Baiana, de descendência africana, protagonizam o a idealização do hibridismo cultural brasileiro.

\section{A conquista de um lugar de fala}

A perspectiva daquele que fala tem sido questão crucial nas discussões contemporâneas; ao mesmo tempo, tem suscitado contrapontos e desconstruções. O lugar de fala da mulher, da mulher negra, do pobre, do homossexual, do transgênero etc. Todos legítimos na medida em que determinam posições, pontos de vista, abordagens. Os artigos desta seção elegem algumas delas, problematizando-as. 
Em "Grito de protesto: a voz da mulher negra em Quarto de despejo - Diário de uma favelada, de Carolina Maria de Jesus" Raimunda Maria dos Santos, Joelma de Araújo Silva Resende e Jandira Lopes Pereira apostam na voz da mulher negra como possibilidade de criação de um espaço de fala do sujeito subalterno, denunciando as desigualdades sociais de uma determinada época e espaço no Brasil.

Sobre a mesma obra, Débora Luciene Porto Boenavides e William Moreno Boenavides, em "Carolina de Jesus, a fome e o leitor: uma análise dialógica de Quarto de Despejo" propõem como base de estudo o método sociológico proposto pelo Círculo de Bakhtin com o objetivo verificar os acarretamentos estilisticos das relações entre autora, herói e ouvinte.

Ana Emília de Lima Ferreira e Thallys Eduardo Nunes de Araújo Oliveira propõem "Subalternidade racial em Torto Arado: do silêncio à resistência", focalizando o processo de tomada de consciência relacionada à condição de subalternidade por preconceito racial no romance. As três narradoras - mulheres negras - que contam a própria história e a do grupo que integram, expressam a submissão das personagens e a tomada de consciência da condição subalterna.

\section{Uma outra subalternidade: para além das em língua portuguesa}

Dialogando com as literaturas em língua portuguesa, no que refere à representação da subalternidade, apresentamos o último artigo que compõe esta edição, que trata do romance do argelino Kamel Daoud. O artigo de Cleide Silva de Oliveira e Sebastião Alves Teixeira Lopes, que tem por título "O caso Meursault, de Kamel Daoud: do silêncio canônico à enunciação pós-colonial" focaliza a reconstrução ficcional da identidae árabe, que, na obra de Albert Camus, $O$ estrangeiro, não se materializa. Assumindo, pois, o caráter de ressignificação do cânone literário, o romance de Daoud é examinado pelos autores do ensaio como a possibilidade de humanização pelo resgate da voz negada no romance anterior.

Assim, convidamos os leitores a compartilharem a produção dos autores que compõem este número da Revista Letrônica, que, ao indagar acerca das personagens subalternas nas literaturas em lingua portuguesa, pretende contribuir para a promoção do exercício da alteridade, tão urgente nos tempos que correm.

\section{Referências}

ADOLFO, Ricardo. Depois de morrer aconteceram-me muitas coisas. Lisboa: Alfaguara, 2009

ADOLFO, Ricardo. Tóquio vive longe da terra. Lisboa: Companhia das Letras Portugal, 2015.

AGUILERA, Fernando Gómez (org.). José Saramago nas suas palavras. Lisboa: Caminho, 2010.

ALMEIDA, Djaimilia Pereira de. Luanda, Lisboa, paraiso. Lisboa: Companhia das Letras Portugal, 2018.

ALMEIDA, Manuel Antonio. Memórias de um sargento de milícias. São Paulo: Ática, 1998

BAUMAN, Zygmunt. Identité et mondialisation. Lignes, Paris, n. 6/3, p. 10-27, 2001. Disponivel em: https://Www cairn.info/revue-lignes1-2001-3-page-10.htm. Acesso em: 3 out. 2021

CANDIDO, Antonio. Formação da literatura brasileira: momentos decisivos. Belo Horizonte: Itatiaia, 1981. v. 1

CANDIDO, Antonio. Dialética da malandragem: caracterização das Memórias de um sargento de milícias. Revista do instituto de estudos brasileiros, São Paulo, n. 8, p. 67-89,1970.

CARDOSO, Dulce Maria. O retorno. Lisboa: Tinta da China, 2011

CHARLES, Sébastien; LIPOVETSKY, Gilles. Les temps hypermodernes. Paris: Grasset, 2004.

CHIAPINNI, Ligia. Formação da literatura brasisleira ou a história de um desejo. Linha D' Água. São Paulo, n. 7. p. 10-23, 1990. Disponivel em: https://www.revistas. usp.br/linhadagua/article/view/37118/39839. Acesso em: 20 out. 2021

CLAVARON, Yves. Repenser les Suds: la réévaluation des géographies subalternes dans les littératures postcoloniales. Revue de littérature comparée, Paris, n. 372 , v. 4, p. 437-451, 2019. Disponivel em: https://www.cairn. info/revue-de-litterature-comparee-2019-4-page-437. htm. Acesso em: 20 ago. 2021

DECLERCQ, Elien. «Écriture migrante », « littérature (im)migrante », « migration literature »: réflexions sur un concept aux contours imprécis. Revue de littérature comparée, Paris, v. 3 n. 339, p. 301-310, 2011.

DERRIDA, Jacques. De la grammatologie. Paris: Minuit, 1967.

FANON, Frantz. Peaux noires, masques blancs. Paris: Seuil, 1952.

FIGUEIREDO, Isabela. Caderno de memórias coloniais Lisboa: Caminho, 2009 
FOKKEMA, Douwe Wessel. Modernismo e pós-modernismo. Lisboa: Vega, 1988.

GEFEN, Alexandre. Responsabilités de la forme: voies et détours de l'engagement littéraire contemporain. L'engagement littéraire. Rennes: Presses Universitaires de Rennes, 2005. p. 75-84. Disponivel em: https://books. openedition.org/pur/30045. Acesso em: 1 out. 2021.

GRAMSCI, Antônio. Cadernos do cárcere. Rio de Janeiro: Civilização Brasileira, 1999-2002. 6 v.

GROSFOGUEL, Ramón. Para descolonizar os estudos de economia politica e os estudos pós-coloniais: Transmodernidade, pensamento de fronteira e colonialidade global. Revista Critica de Ciências Sociais, Coimbra, $\mathrm{n}$. 80, p. 115-147, 2012. https://doi.org/10.4000/rccs.697.

JORGE, Lídia. A costa dos murmúrios. Lisboa: Dom Quixote, 1988.

JORGE, Lídia. O vento assobiando nas gruas. Lisboa: Dom Quixote, 2002.

LYOTARD, Jean François. La condition postmoderne. Paris: Minuit, 1979.

HUTCHEON, Linda. Ironie et parodie: stratégie et structure. Poétique: revue de théorie et d'analyse litteraires, Toronto, n. 36, p. 467-477, nov. 1978. Disponivel em: https://tspace.library.utoronto.ca/handle/1807/10265. Acesso em: 21 ago. 2021.

HUTCHEON, Linda. A poetics of postmodernism: history, theory, fiction. London; New York: Routledge, 1988.

KILOMBA, Grada. Mémoires de la plantation: épisodes de racisme ordinaire. Paris: Anacaona, 2021.

MÃE, Válter Hugo. O apocalipse dos trabalhadores. Porto: QuidNovi, 2008.

MACEDO, Joaquim Manuel de. A moreninha. São Paulo: Ática, 1982.

MIGNOLO, Walter. Local Histories/Global Designs. Coloniality, Subaltern Knowledges and Border Thinking. Princeton: Princeton University Press, 2000.

QUEIRÓS, José Maria Eça de. O primo Basilio. Porto: Porto, 2010.

QUIJANO, Aníbal. Colonialidad del poder y clasificación social. Journal of world-systems, California v. 11 n. 2, p. 342-386, 2000.

QUIJANO, Anibal. «Race » et colonialité du pouvoir. Mouvements, Paris: La Découverte, v. 51, n. 3, p. 111118, 2007.

REIS, Carlos. História crítica da literatura portuguesa: do neo-realismo ao post-modernismo. Lisboa: Verbo, 2005.

RESENDE, Beatriz. Lima Barreto e o Rio de Janeiro em fragmentos. São Paulo: Autêntica, 2016.

RIBEIRO, Djamila. O que é lugar de fala? Belo Horizonte: Letramento, 2017.
ROCHA, João César do Castro. A Guerra dos relatos no Brasil contemporâneo. Ou: "a dialética da marginalidade". Letras - Revista do Programa de Pós-Graduação em Letras da UFSM, Santa Maria, n. 32, p. 23-70, jun. 2006 Disponivel em: https://periodicos.ufsm.br/letras/ issue/view/652/showToc. Acesso em: 20 set. 2021.

SARAIVA, António José; LOPES, Óscar O. História da literatura portuguesa. Porto: Porto Editora, 2005.

SARAMAGO, José. Levantado do chão. Lisboa: Caminho, 1980

SCHAWARZ, Roberto. A velha pobre e o retratista. In: SCHAWARZ, Roberto (org.). Os pobres na literatura brasileira. São Paulo: Brasiliense, p. 46-60, 1983.

SPIVAK, Gayatri. In other worlds: essays in cultural politics. New York: Routledge, 1988.

SPIVAK, Gayatri. Pode o subalterno falar? Belo Horizonte: Editora UFMG, 2010 [1985].

PEIXOTO, José Luís. Livro. Lisboa: Quetzal, 2010.

ZINK, Rui. O destino turistico. Lisboa: Teorema, 2008.

\section{Maria Tereza Amodeo}

Doutora em Linguística e Letras pela Pontificia Universidade Católica do Rio Grande do Sul (PUCRS), em Porto Alegre, RS, Brasil; mestre em Linguística e Letras pela mesma instituição; professora titular da Pontifícia Universidade Católica do Rio Grande do Sul (PUCRS), em Porto Alegre, RS, Brasil.

\section{Sílvia Amorim}

Doutora em Estudos dos Países de Língua Portuguesa pela Universidade de Paris 8 - Vincennes - Saint-Denis; professora titular no departamento de Português da Universidade Bordeaux Montaigne, na França.

\section{Ívens Matozo Silva}

Mestre em Letras pela Universidade Federal de Pelotas (UFPel), em Pelotas, RS, Brasil. Doutorando em Teoria da Literatura pela Pontifícia Universidade Católica do Rio Grande do Sul (PUCRS), em Porto Alegre, RS, Brasil. Bolsista CNPq.

\section{Endereços para correspondência}

Maria Tereza Amodeo

Pontifícia Universidade Católica do Rio Grande do Sul Avenida Ipiranga, 6681, Prédio 8, sala 401/08

Partenon, 90619-900

Porto Alegre, RS, Brasil 
Silvia Amorim

Université Bordeaux Montaigne

Domaine Universitaire

19 Esplanade des Antilles

F33607 Pessac Cedex

France

Ívens Matozo Silva

Pedro Palmeiro, 2200

Lulu Genro, 97707-045

Santiago, RS, Brasil

Os textos deste artigo foram revisados pela Poá Comunicação e submetidos para validação do(s) autor(es) antes da publicação. 